\title{
Association of CYPA1 gene polymorphism with plasma nitric oxide levels in COPD
}

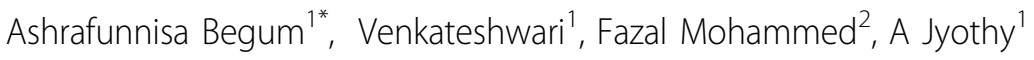 \\ From 2nd International Genomic Medical Conference (IGMC 2013) \\ Jeddah, Kingdom of Saudi Arabia. 24-27 November 2013
}

\section{Background}

Chronic obstructive pulmonary disease (COPD) is characterized by irreversible airflow limitation, abnormal permanent distal air-space enlargement and emphysema in the lungs. Increased oxidative burden in COPD is because of both directly a result of smoking and indirectly by the release of increasing amount of ROS from airways leukocytes. The CYP1A1 gene modifies the phase I enzyme aryl hydrocarbon hydroxylase (AHH) belonging to the cytochrome P450 system that plays a major role in the metabolism of exogenous toxins generated by cigarette smoke [1]. The aim of the present study is to assess the role of CYP1A1 gene polymorphism and to measure the plasma nitric oxide levels in the etiology of COPD in South Indian Population from Andhra Pradesh.

\section{Materials and methods}

A cohort of 250 clinically and spirometrically confirmed COPD patients referred to Government Chest Hospital, Hyderabad and an equal member of age and sex matched control subjects were included in the present study. Genotyping of CYP1A1 gene polymorphism was done by PCR - RFLP method followed by agarose gel electrophoresis. The plasma nitrite levels were estimated by spectrophotometric method. Appropriate statistical methods were applied to test for the significance of the results.

\section{Results}

Genotypic distribution of CYP1A1 gene polymorphism revealed $36.8 \%$ of TT, $50.8 \%$ of TC and $12.4 \%$ of CC genotypes in COPD patients and $44.8 \%$ of TT, $48.4 \%$ of

\footnotetext{
* Correspondence: ashraf_begum786@yahoo.co.in

${ }^{1}$ Institute of Genetics and Hospital for Genetic Diseases, Osmania University, Hyderabad 500016, India

Full list of author information is available at the end of the article
}

TC and $6.8 \%$ of CC in control subjects (Figure 1). There is an increased frequency of CC genotype and $\mathrm{C}$ allele in the COPD patients compared to control subjects $\left(X^{2}=4.51 ; \mathrm{p}=0.03 ; \mathrm{OR}=1.94 ; 95 \% \mathrm{CI}=(1.044-3.605)\right.$ and $\left(X^{2}=5.12 ; \mathrm{p}=0.02 ; \mathrm{OR}=1.35 ; 95 \% \mathrm{CI}=(1.041-1.758)\right.$. (Table 1). The study carried out from North Indian population have shown that CYP1A1,-3801 polymorphism was significantly associated with COPD [2]. The mean levels of plasma nitrite levels were also found to significantly elevated in COPD patients $(2.715 \pm 1.552)$

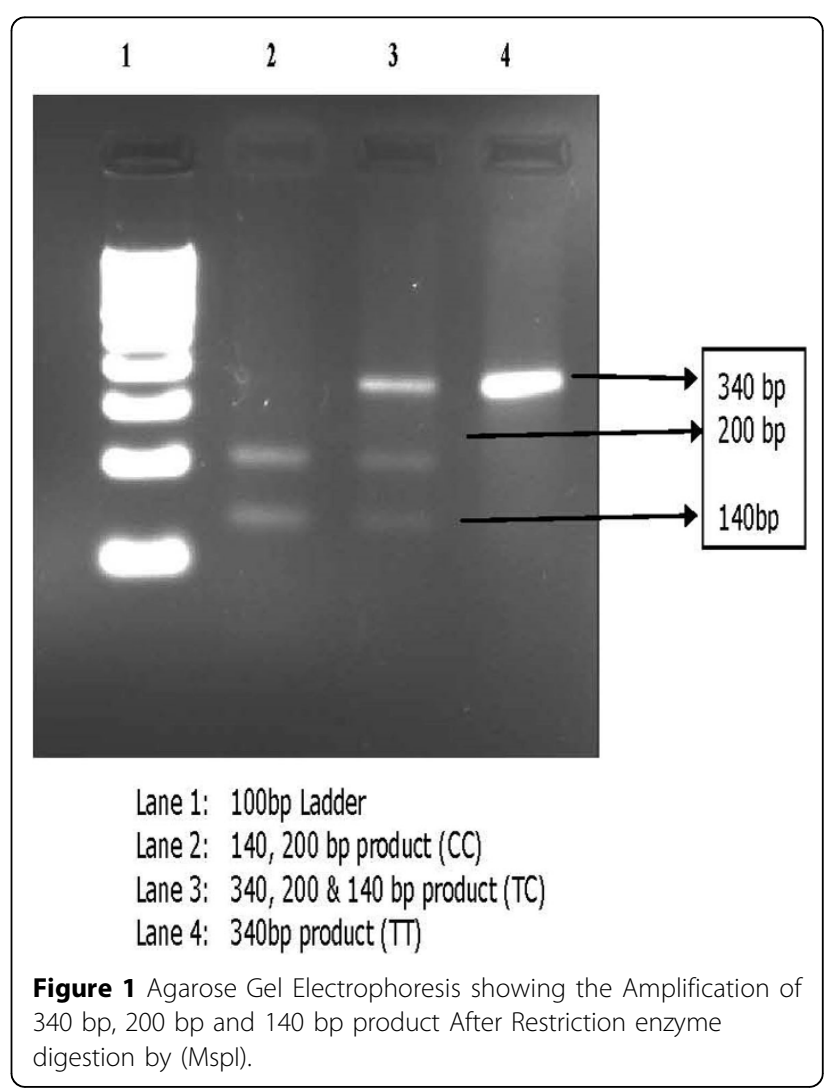


Table 1 Comparison of genotypes and alleles of CYPA1$3801 \mathrm{~T} / \mathrm{C}$ in COPD and Controls

\begin{tabular}{llll}
\hline$X^{2}$ & p Value & Odds Ratio 95\% Cl & Genotype/Allele \\
\hline TT Vs TC + CC & 3.31 & 0.06 & $0.71(0.5015-1.026)$ \\
TC Vs T+CC & 0.28 & 0.59 & $1.10(0.7752-1.563)$ \\
CCVs TC + TT & 4.51 & 0.03 & $1.94(1.044-3.605)$ \\
C Vs T & 5.12 & 0.02 & $1.35(1.041-1.758)$ \\
T Vs C & 5.12 & 0.02 & $0.73(0.56-0.960)$ \\
\hline
\end{tabular}

in comparison with their respective controls $(1.123 \pm$ $0.699)(\mathrm{p}<0.001)(\mathrm{t}$ value $=2.6449)$.

\section{Conclusions}

The present study indicates the association of CYP1A1 gene polymorphism and plasma nitric oxide levels in the etiology of COPD patients of South Indian population from Andhra Pradesh.

\section{Authors' details}

'Institute of Genetics and Hospital for Genetic Diseases, Osmania University, Hyderabad 500016, India. ${ }^{2}$ Vita Food Company, Dammam, KSA.

Published: 2 April 2014

\section{References}

1. Kiyohara C, Hirohata T, Inusuka S: The relationship between aryl hydrocarbon hydroxylase and polymorphisms of CYP1A1 gene. Jpn J Cancer Res 1996, 87:18-24.

2. Arpana Vibhuti, Ehtesham Arif, Aastha Mishra, Desh Deepak, Bhawani Singh, Irfan Rahman, Ghulam Mohammad: CYP1A1, CYP1A2 CYBA gene polymorphisms associated with oxidative stress in COPD. Clinica Chimica Acta 2010, 411:7-8, 474-480.

doi:10.1186/1471-2164-15-S2-P9

Cite this article as: Begum et al:: Association of CYPA1 gene

polymorphism with plasma nitric oxide levels in COPD. BMC Genomics 2014 15(Suppl 2):P9.

Submit your next manuscript to BioMed Central and take full advantage of:

- Convenient online submission

- Thorough peer review

- No space constraints or color figure charges

- Immediate publication on acceptance

- Inclusion in PubMed, CAS, Scopus and Google Scholar

- Research which is freely available for redistribution

Submit your manuscript at www.biomedcentral.com/submit
C Biomed Central 